\title{
Towards health-promoting and environmentally friendly regional diets - a Nordic example
}

\author{
Elling Bere ${ }^{1, *}$ and Johannes Brug ${ }^{2}$ \\ ${ }^{1}$ Faculty of Health and Sport, University of Agder, Serviceboks 422, 4604 Kristiansand, Norway: \\ ${ }^{2}$ EMGO Institute, VU University Medical Center, Amsterdam, The Netherlands
}

Submitted 22 August 2007: Accepted 20 January 2008: First published online 14 March 2008

\begin{abstract}
Background: Because most of the top determinants of the worldwide burden of disease are diet-related, the promotion of healthful diets is important for population health across the world. Furthermore, changes in eating habits may contribute to preservation of the environment.

Objective: In the present paper it is argued that the translation of health-promoting dietary recommendations into practical recommendations for healthful eating should be more tailored to regional circumstances. This will promote population health as well as help preserve cultural diversity in eating habits and contribute to more environmentally friendly eating. A regional Nordic diet, mimicking the Mediterranean diet to some extent, is presented as an example. Conclusion: A theoretically health-enhancing Nordic diet is possible including six evidence-based ingredients: (i) native berries; (ii) cabbage; (iii) native fish and other seafood; (iv) wild (and pasture-fed) land-based animals; (v) rapeseed oil; and (vi) oat/barley/rye.
\end{abstract}

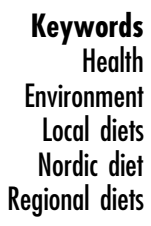

Since most of the top determinants of the burden of disease are diet-related $^{(1)}$, healthy diet promotion is important for population health across the world. Promoting healthy diets is therefore an important aspect of prevention policies in many countries, and the recommendations for healthful eating are very similar across countries ${ }^{(2)}$. In the present paper we argue that the translation of health-promoting dietary recommendations into practical recommendations for healthful eating should be more tailored to regional circumstances. Such regional tailoring of recommendations may help to preserve cultural diversity in eating habits. Furthermore, since environmental preservation and sustainability may become a major public health challenge ${ }^{(3)}$, healthy diet promotion should also take environmental sustainability into account and regionally defined diets may contribute to more environmentally friendly eating, on top of promoting physical health. We propose a rational and possible content for a regional Nordic diet to build our case for such regionalization of recommendations.

\section{Nutrients and foods}

In the promotion of healthful eating, basically two different avenues are explored. The first is the nutrients way, with a focus on the identification of key nutrients and other food compounds that help prevent disease and promote health. This road leads to nutrient-specific recommendations (e.g. the Nordic nutrition recommendations ${ }^{(4)}$ ), the use of dietary supplements, nutrient enrichment or fortification of foods, and the development of functional foods. This avenue has been fruitful in the past where the identification of specific essential nutrients, nutrient requirements, and enrichment, fortification or supplementation schemes have helped to eradicate a number of deficiency diseases in large parts of the world.

However, this nutrient-oriented avenue in general appears to be less effective in addressing the most important present-day nutrition-related health problems, which are related to over-consumption rather than deficiencies and more strongly related to foods and eating patterns than to nutrients. For example, the main causes of morbidity and mortality in most countries are CVD and cancer. Although there is ample evidence that nutrition is directly or indirectly related to CVD and cancer risk, as well as a number of other chronic diseases ${ }^{(5)}$, there is only very little evidence that specific nutrients contribute to the prevention of CVD or cancer. For example, two recent reviews reported no clear effect of supplementation with antioxidants $^{(6)}$ or $n-3$ fatty acids ${ }^{(7)}$ on mortality, and it is highly probable that it is whole foods (e.g. fruits, vegetables, fish) and dietary patterns, rather than specific nutrients, that are inversely related with disease risks.

The second avenue is therefore food- and food patterns-oriented. This avenue is more closely linked to what people eat - that is foods, not nutrients - and incorporates the fact that nutrients do not function in an isolated 
manner, but might interact with other nutrients and food compounds. Different food guide pyramids, food plates and other nutrition education tools build on this foodoriented avenue. Generally, in most countries four or five basic food groups are recognized that contribute to a balanced healthful diet: (i) bread, rice, cereals and other foods rich in starch; (ii) fruits and vegetables; (iii) dairy products; (iv) meat, fish and alternatives; and (v) oils and fats. Experts generally agree that some food groups, the fruit and vegetable group in particular, should be encouraged, and that within each food group some foods should be encouraged and others should be discouraged. For example, it is recommended to choose fibre-rich products such as wholemeal breads within the starch food group, to choose low-fat varieties in the dairy group, to prefer fish and poultry above red meat in the meat and fish group, and to prefer plant oils low in SFA above animal fats within the oils and fats group ${ }^{(2)}$.

\section{From foods to meals and whole diets}

Some attempts have been made to take this food-oriented avenue a few steps further, by describing meal patterns or diets that incorporate the foods for which the strongest evidence has been found for a health-enhancing effect. The best known and best researched example is what has been labelled the 'Mediterranean diet'. Ancel Keys first reported the health benefits of the traditional Cretan diet in the $1950 \mathrm{~s}^{(8)}$; however, the Mediterranean diet failed to gain widespread recognition until the 1990s. Since then, its popularity among nutrition scientists has been increasing (PubMed finds 115 papers about the Mediterranean diet published in 2005 and 149 in 2006), and the 996000 hits on www.google.com (accessed June 2007) indicates a strong interest also among the general population. Although across the Mediterranean a wide variety of diets is present, the health-enhancing Mediterranean diet is supposed to include olive oil, fruits, vegetables, grains (mostly unrefined), fish, diary in moderate amounts, low quantities of meat and meat products, and a regular but moderate intake of alcohol ${ }^{(9)}$. Several recent review articles state that adherence to a Mediterranean-style diet is protective against lifestyle diseases such as CVD, obesity, type 2 diabetes mellitus and certain cancers ${ }^{(10-12)}$. Together with regular physical activity and not smoking, Willett has calculated that $80 \%$ of CHD, $70 \%$ of stroke and $90 \%$ of type 2 diabetes can be avoided by healthy food choices that are consistent with the Mediterranean diet ${ }^{(13)}$.

Attempts have been made to promote this Mediterranean diet outside the Mediterranean countries, for example in Scotland ${ }^{(14)}$, The Netherlands ${ }^{(15)}$ and the $\mathrm{USA}^{(16)}$. However, it is questionable that such a specific, regionally defined diet is applicable and advisable all over the world ${ }^{(17)}$. Several of the ingredients of the Mediterranean diet do not grow well in many areas (e.g. in the Nordic countries), therefore requiring greenhouses or long-distance transportation. Other ingredients are not available in large enough quantities to be included in diets across the world. Furthermore, most countries or regions do have their own culturally and regionally appropriate foods that might be as health-enhancing as the ingredients for the Mediterranean diet. For example, Japan has today the highest life expectancy in the world $^{(18)}$, possibly in part due to their diet ${ }^{(19)}$, which differs from the Mediterranean diet in some aspects (less fat and less fruits) but is similar in others (inclusion of local types of grains, legumes, vegetables and fish) ${ }^{(19)}$.

Traditionally regionally available foods have been and still are being replaced by modern industrial and processed foods all over the world. Such processed foods often tend to be sweeter, fattier and saltier, as well as highly available, ready-to-eat and cheap ${ }^{(20)}$. This rapid change of our food environment has been suggested as an ultimate determinant for several of the lifestyle diseases we cope with at present $^{(21)}$. Today, people tend to forget the traditional regional foods upon which their ancestors lived and survived for ages. It has been suggested that the healthpromoting properties of the Mediterranean diet might be due to its closer reflection of the diet our hunter-gatherer ancestors ate than that attained by most other Western diets $^{(17)}$. Regional diets also might provide climate-, soiland culturally appropriate ingredients for health-enhancing eating in present-day societies.

\section{Food in relation to the environment}

In addition to impacting health, what we eat also strongly influences our environment. The way most of us feed ourselves in affluent societies is not sustainable. For example, the livestock sector, which produces our meat and milk products, is responsible for a total of $18 \%$ of anthropogenic greenhouse gas emissions measured in $\mathrm{CO}_{2}$ equivalents ${ }^{(22)}$. This is a higher share than for transportation. A second example is that the biomass of high trophic level fishes (larger predatory fish, e.g. cod) in the North Atlantic has declined by a factor of nine over the last century because of over-fishing practices ${ }^{(23)}$. Other examples of the environmental effects of food production are plentiful: soil erosion, over-consumption of fresh water, monoculture (reduces both plant and animal biodiversity), and pesticides and fertilizers polluting soil, water and air $^{(24)}$. In addition, most foods eaten today travel long distances, demanding additional fossil fuel, before they reach the dinner table ${ }^{(25)}$.

\section{A healthier and more environmentally friendly Nordic diet}

It seems reasonable to explore if locally oriented and culturally appropriate dietary patterns can be identified in areas other than around the Mediterranean. As a first 
exploration, we present possibilities of a culturally and geographical approach for the Nordic countries, including locally appropriate ingredients for each of the different food groups. Foods available or potentially available in Norway are used as a main example.

\section{Food production, import and export in Norway}

Most meat, fish, eggs, milk and milk products consumed in Norway are produced domestically ${ }^{(26)}$, traditionally at relatively small-scale farms. The main farm animals, sheep and cows, are predominantly pasture-fed, at least for the snow-free part of the year. However, there is a tendency towards a more industrialized production. The importation of some other foods to Norway is large; all sugar, about $93 \%$ of fruits and berries, more than $80 \%$ of oils/fats, $47 \%$ of vegetables, $36 \%$ of grains and about $20 \%$ of potatoes eaten in Norway are imported ${ }^{(26)}$. The relative contribution of imports to the intake of fruits (up from $57 \%$ in the 1950 s to $93 \%$ in 2004) and vegetables (up from $7 \%$ to $47 \%$ ) has increased drastically. At the same time, Norway is a major exporter of fish, both wild fish (e.g. cod) and farmed fish (e.g. salmon). Few other foods are exported.

\section{Ingredients for a Nordic diet}

In order to choose ingredients for a more health-enhancing and environmentally friendly Nordic diet, four criteria were set:

1. Ability to be produced locally over large areas within the Nordic countries without usage of external energy e.g. for the production of greenhouses.

2. A tradition as a food source within the Nordic countries.

3. Possessing a better potential for health-enhancing effects than similar foods within the same food group.

4. Ability to be eaten as foods, not only in small amounts as dietary supplements (e.g. spices).

Since man is an omnivore, both animal and plant foods were considered, and the ingredients together must provide the basic essential nutrients needed, including energy requirements.

\section{Ingredient 1: Native berries}

Several edible wild berries grow in large areas within the Nordic countries and several cultivated berries grow well in home gardens. Researchers at Bioforsk (Norwegian Institute for Agricultural and Environmental Research) have estimated that the annual blueberry and cowberry production in Norwegian productive forests is between 120 and 220 million $\mathrm{kg}^{(27)}$, which alone is almost the recommended 2-a-day of fruits for all Norwegians (the definition of one portion of berries is $\left.1-2 \mathrm{dl}^{(28)}\right)$. In addition, there is considerable blueberry and cowberry production in non-productive forest and mountain areas, there are at least twenty-eight other edible wild berries in Norway ${ }^{(29)}$, and berries are grown in many private or semi-public gardens across Norway. However, the consumption of berries is low and figures from Norway show that it is declining (down from $7 \cdot 0$ to $3 \cdot 7 \mathrm{~kg} /$ year from 1977 to 2000; L Johansson, Directorate for Social Affairs and Health, personal communication). In Sweden, it has been reported that only 5-6\% of wild blueberries, cowberries and raspberries were picked in $1977^{(29)}$.

In a Norwegian study assessing concentrations in 124 plant foods, berries were identified as the plant foods with some of the highest levels of total antioxidants ${ }^{(30)}$. A recent study showed that three wild berries (blueberries, cloudberries, cowberries) also contain significant amounts of $n-3$ fatty acids; indeed, in the same amounts as found in fish, when measured per unit of energy, and more than fifteen times greater than levels found in the three most commonly eaten fruits in Norway ${ }^{(31)}$. The same study showed that a higher consumption of these three berries would improve Norwegian diets also on a selection of nutrients not commonly associated with fruits or berries ${ }^{(31)}$.

\section{Ingredient 2: Cabbage}

Cabbage, kale, kohlrabi, broccoli, cauliflower and Brussels sprouts are all varieties of the same species (wild cabbage, Brassica oleracea) and have been included in Nordic diets for a very long time. Cabbage thrives in cold climates ${ }^{(32)}$ and grows well in the Nordic countries. Production in Norway of cabbage (all types) in 2005 was $32 \cdot 3$ million $\mathrm{kg}^{(26)}$, which corresponds to only about $0 \cdot 1$ portion daily per person (the definition of one portion of vegetables is $\left.150 \mathrm{~g}^{(28)}\right)$. A total of $76 \%$ of all cabbage eaten in Norway is produced domestically and the production has been rather stable over the last 30 years ${ }^{(26)}$

Together with other close relatives, such as rutabaga, turnip, radish, rape and mustard, cabbage constitutes the group of cruciferous vegetables. Cruciferous vegetables are known for their probable cancer-preventing effect ${ }^{(33)}$. Cabbage is also a very good source of vitamin $\mathrm{K}^{(34)}$ and contains ample amounts of $n-3$ fatty acids ${ }^{(35)}$. Some types (kale, red cabbage and Brussels sprouts) also contain more antioxidants than most other vegetables ${ }^{(30)}$. Several of the cruciferous vegetables are also considered among the 'dark green leafy vegetables' which are known as excellent sources of fibre, folate and a wide range of carotenoids.

\section{Ingredient 3: Native fish and other seafood}

The Nordic countries have long coastlines, several fjords, rivers and lakes, and as such have great access to fish as well as other seafood such as shrimps, mussels and marine mammals. In Norway there is also a large production of cultivated fish. Catch of seafood by Norwegian fisheries registered in Norway has been between 2500000 and 3000000 tonnes per annum in recent years ${ }^{(36)}$. Production of cultivated seafood (mainly salmon and trout) was 600000 tonnes in $2005^{(37)}$, of which $95 \%$ was exported ${ }^{(26)}$. Cod-liver oil has a long tradition as a dietary supplement in Norway. 
Seafood, and especially fatty fish, is regarded by many nutritionists as well as consumers as healthy food. This is mainly because of its content of essential fatty acids (especially long-chain $n-3$ fatty acids such as EPA and DHA) and because it is an important dietary source of vitamin D. In addition, seafood is also a great source of Se and $\mathrm{I}$, as well as of protein and vitamin $\mathrm{B}_{12}$.

\section{Ingredient 4: Wild and pasture-fed land-based animals} There are large areas within the Nordic countries that are not suitable for modern agricultural production, but where several wild animals thrive. Several species are hunted for their meat: moose, different deer species, hare, and birds like goose, duck and grouse. The total net weight of hunted moose, deer and reindeer in 2003 was 6700 tonnes $^{(38)}$. Because the Nordic countries possess large areas of land compared with the number of people, the potential for domesticated pasture-fed meat (and milk products from pasture-fed animals) is greater than in most countries across Europe. In addition to reindeer, several sheep, goats and cows are pasture-fed and in fact live rather similarly to wild animals with the possibility to roam freely across large areas, at least for part of their lives.

A special trait for domesticated animals is that they contain much subcutaneous adipose tissue (and for beef and mutton, also bands of fat through the muscles, i.e. marbling) ${ }^{(39)}$, which is made up mainly of SFA ${ }^{(40)}$. Meat from wild mammals diverges from meat from domesticated mammals in that it is leaner (fat is usually stored around organs such as kidneys and not around muscles) and, probably more important, the fatty acid composition is better (i.e. less SFA, more PUFA) ${ }^{(40)}$. Pasture-fed meat has a fat content and fatty acid profile in between wild and feedlot-fed meat ${ }^{(40)}$. All meat is an excellent source of protein, Fe and vitamin $B_{12}$, as well as a number of other essential nutrients.

\section{Ingredient 5: Rapeseed oil}

Rape (Brassica napus) is a cruciferous vegetable. At present there is an increase in rapeseed oil production in the Nordic countries, both for production of edible rapeseed oil and for bio-fuel. Rapeseed oil is commonly used for cooking, in dressings and also in industrialized food products (from frozen pizzas to baby food).

In rapeseed oil (and also canola oil, a Canadian trademarked cultivar of rapeseed oil), as in olive oil, the majority of the fatty acids are monounsaturated. In addition, rapeseed oil contains more PUFA and especially more $n$ - 3 fatty acids than olive oil, and it has a more favourable $n-6: n-3$ ratio. Rapeseed oil therefore possesses a better fatty acid profile than most edible oils and fats (see e.g. www.nal.usda.gov/fnic/foodcomp/search/), and a substitution of some of our daily fat/oil intake with rapeseed oil could be beneficial for health. Rapeseed oil also appears to be a good source of vitamin E.
Ingredient 6: Oat/barley/rye

Today, about $85 \%$ of all grains consumed in Norway is wheat $^{(41)}$. Oat, barley and rye all grow better in a cold climate than wheat, and a higher share of oat/barley/rye than wheat is produced domestically in Norway ${ }^{(41)}$. Indeed, more area in Norway is used to produce oat/barley/rye (mostly oat and barley) than for wheat production ${ }^{(38)}$, but most of the oat and barley is used to feed animals.

Wheat is usually eaten as white flour while oat/barley/ rye more often is eaten as whole grains, and therefore oat/ barley/rye products tend to have a lower glycaemic index than wheat products ${ }^{(42)}$. The WHO states that whole grains are related to most preventable chronic diseases through their high content of NSP ${ }^{(5)}$. Furthermore, compared with wheat, oat/barley/rye (especially oat and barley) contain more antioxidants ${ }^{(30)}$, more $\beta$-glucans and less gluten. As Norwegians also eat a very large amount of wheat (about $20 \%$ of the total energy we consume comes from wheat, the highest amount from any single species; calculated from data published by Sosial- og helsedirektoratet ${ }^{(26,43)}$ ) but are recommended to eat a variety of foods, a substitution of some of the wheat with oat/barley/rye could not be anything than beneficial for health.

\section{Challenges with the 'new Nordic diet'}

In the present paper a case has been made for a more regionally oriented approach to a health-promoting whole diet that may also contribute to environmental sustainability. Such regionally defined diets are similar to the approach of the traditional Mediterranean diet and it also links to ideas and practices promoted by the so-called 'slow food movement' (www.slowfood.com/), which also favours regional foods, but from a more food culture orientation next to sustainability. It is also much in line with the principles of the New Nutrition Science Project, a joint effort by several prominent nutrition scientists to assess not only personal and population health, but also planetary health ${ }^{(44)}$. In the present paper ingredients for a 'new Nordic diet' were introduced as an example of a regionally defined health-promoting diet. Preliminary existing evidence was summarized regarding the health-enhancing properties of these ingredients. However, the regionally appropriate Nordic diet is at present just a theoretically possible approach; putting this into practice comes with many challenges and more research is necessary before it can actually be promoted.

A first important challenge is associated with the inclusion of fish and meat from game. Today's industrialized production of both meat and fish clearly has large ecological consequences $^{(22,24,45)}$. Wild game and wild fish pose a potential for meat and fish production with a much smaller ecological impact, as well as foods with a more favourable fatty acid profile. However, a major problem is over-hunting and -fishing. Populations of most large, wild, land-based mammals 
are now only fragments of what they were before the human population explosion, and several large land-based mammals and birds have been hunted to extinction throughout human history ${ }^{(46)}$. Meat and poultry are good sources of protein and Fe. However, people can get protein from other sources, and a sufficient $\mathrm{Fe}$ intake is also possible without eating animal products. Animal products are also the only source of vitamin $\mathrm{B}_{12}$, but this can be obtained from other animalbased foods than meat. Meat from game and poultry is therefore not a necessary ingredient of a healthy diet, the Nordic diet included, especially when fish is available. Regarding land-based meat, the only long-term sustainable solution, as long as the human population is increasing worldwide, appears to be to eat much less than present-day average consumption levels, which also is in accordance with current nutrition recommendations. So, because of livestock meat's high saturated fat content and its large ecological impact, meat should be eaten in modest amounts. For such small amounts of meat, meat from wild and pasture-raised animals is to be preferred.

Similarly to game, several of the oceans' fish stocks have now collapsed, and the future harvest depends heavily on how the remaining stocks are and will be treated $^{(47-49)}$. It is striking how much wild seafood is harvested in Norway, and this large seafood harvest is more than enough to provide Norwegians with goodquality animal food. However, Norway is a special country with few people and a very long coastline. Since on a global scale there certainly is not enough wild seafood to be harvested to enable people to eat the often recommended two servings of seafood per week ${ }^{(50)}$, the present-day 'eat more seafood' promotion may be ethically questionable. Fish is especially recommended because of its high levels of $n$ - 3 fatty acids. However, wild berries $^{(31)}$, cabbage ${ }^{(35)}$ and rapeseed oil contain $n-3$ fatty acids and have a low/favourable $n-6: n-3$ ratio, and eating such foods in higher quantities makes fish a less needed ingredient of the Nordic diet.

A second challenge is whether all the plant food we need can be produced and harvested locally. The production of wild berries varies between years due to growth factors such as temperature. However, the amounts of wild berries do appear large. Additionally, many people in Nordic countries have a private garden or have access to a community garden, where often berries are produced. Such gardens can also be used for the production of other plant foods, including cabbage and other cruciferous vegetables (e.g. rutabaga, turnip and radish). A lower consumption of animal food (as discussed above) will also free land areas that can be used for the production of oat/barley/rye, rapeseed, cabbage and berries for human consumption.

Identifying which foods could be included in a healthpromoting regionally defined diet is only a first step. The next and much more complicated challenge is how to get people to indeed eat these foods instead of the foods they have grown accustomed to. In affluent countries, most people can generally choose what, when and how much they eat. Therefore, a major challenge is to get people to choose to eat in accordance with regional diets such as the Nordic example. To promote healthy food choices in a planned way, insight is necessary into why people choose to eat what they do ${ }^{(51)}$, i.e. the determinants of food choice. A framework proposed by Rothschild ${ }^{(52)}$ provides a simple, integrative approach to categorize the large and diverse number of potential personal and environmental determinants from various more specific behaviour theories. In this framework three categories of determinants are distinguished: motivation, ability and opportunity. In order to effectively promote the Nordic diet ingredients, people should be motivated to eat these foods, should have or obtain the abilities to choose wisely from these ingredients and to prepare palatable entrees and meals, and the ingredients should be highly available and accessible so that they have plenty of easy opportunities to include these ingredients in their diets.

\section{Concluding remarks}

We suggest six ingredients for a new healthier and more environmental friendly Nordic diet: (i) native berries; (ii) cabbage; (iii) native fish and other seafood; (iv) wild (and pasture-fed) land-based animals; (v) rapeseed oil; and (vi) oat/barley/rye.

\section{Acknowledgements}

The authors declare that they have no competing interest. E.B. and J.B. wrote the paper together. The paper does not belong to any specific project, and has therefore no specific source of funding. No acknowledgements.

\section{References}

1. Ezzati M, Lopez AD, Rodgers A, Vander Hoorn S \& Murray CJL (2002) The Comparative Risk Assessment Collaborating Group. Selected major risk factors and global and regional burden of disease. Lancet 360, 1347-1360.

2. Brug J \& Oenema A (2006) Healthful nutrition promotion in Europe: goals, target populations, and strategies. Patient Educ Couns 63, 255-257.

3. Mackenbach JP (2007) Global environmental change and human health: a public health research agenda. J Epidemiol Community Health 61, 92-94.

4. Nordic Council of Ministers (2005) Nordic Nutrition Recommendations 2004. Copenhagen: Nordic Council of Ministers.

5. World Health Organization (2003) Diet, Nutrition and the Prevention of Chronic Diseases. Report of a Joint WHO/FAO Expert Consultation. Technical Report Series no. 916. Geneva: WHO.

6. Bjelakovic G, Nikolova D, Gluud LL, Simonetti RG \& Gluud C (2007) Mortality in randomized trials of antioxidant supplements for primary and secondary prevention: systematic review and meta-analysis. JAMA 297, 842-857. 
7. Hooper L, Thompson RL, Harrison RA et al. (2006) Risks and benefits of omega 3 fats for mortality, cardiovascular disease, and cancer: systematic review. BMJ 332, $752-760$.

8. Keys AB (1980) Seven Countries: A Multivariate Analysis of Death and Coronary Heart Disease. Cambridge, MA: Harvard University Press.

9. Trichopoulou A, Costacou T, Bamia C \& Trichopoulos D (2003) Adherence to a Mediterranean diet and survival in a Greek population. $N$ Engl J Med 348, 2599-2608.

10. Schroder H (2007) Protective mechanisms of the Mediterranean diet in obesity and type 2 diabetes. $J$ Nutr Biochem 18, 149-160.

11. de Lorgeril M \& Salen P (2006) The Mediterraneanstyle diet for the prevention of cardiovascular diseases. Public Health Nutr 9, 118-123.

12. Colomer R \& Menendez JA (2006) Mediterranean diet, olive oil and cancer. Clin Transl Oncol 8, 15-21.

13. Willett WC (2006) The Mediterranean diet: science and practice. Public Health Nutr 9, 105-110.

14. Papadaki A \& Scott JA (2005) The Mediterranean eating in Scotland experience project: evaluation of an Internetbased intervention promoting the Mediterranean diet. Br J Nutr 94, 290-298.

15. Bemelmans WJ, Broer J, Feskens EJ, Smit AJ, Muskiet FA, Lefrandt JD, Bom VJ, May JF \& Meyboom-de Jong B (2002) Effect of an increased intake of $\alpha$-linolenic acid and group nutritional education on cardiovascular risk factors: the Mediterranean Alpha-linolenic Enriched Groningen Dietary Intervention (MARGARIN) study. Am J Clin Nutr 75, 221-227.

16. Toobert DJ, Glasgow RE, Strycker LA, Barrera M, Ritzwoller DP \& Weidner G (2007) Long-term effects of the Mediterranean lifestyle program: a randomized clinical trial for postmenopausal women with type 2 diabetes. Int $J$ Behav Nutr Phys Act 4, 1.

17. Mackenbach JP (2007) The Mediterranean diet story illustrates that 'why' questions are as important as 'how questions in disease explanation. J Clin Epidemiol 60, 105-109.

18. World Health Organization (2007) World Health Statistics 2007. Geneva: WHO.

19. Willett WC (1994) Diet and health: what should we eat? Science 264, 532-537.

20. Drenowski A \& Darmon N (2005) Food choices and diet costs: an economic analysis. J Nutr 135, 900-904.

21. Eaton SB, Strassman BI, Nesse RM et al. (2002) Evolutionary health promotion. Prev Med 34, 109-118.

22. Steinfeld H, Gerber P, Wassenaar T, Castel V, Rosales M \& de Haan C (2006) Livestock's Long Shadow. Environmental Issues and Options. Rome: FAO.

23. Christensen V, Guenette S, Heymans JJ, Walters CJ, Watson R, Zeller D \& Pauly D (2003) Hundred-year decline of North Atlantic predatory fishes. Fish Fisheries $\mathbf{4}, 124$.

24. Horrigan L, Lawrence RS \& Walker P (2002) How sustainable agriculture can address the environmental and human health harms of industrial agriculture. Environ Health Perspect 110, 445-456.

25. Pretty JN, Ball AS, Lang T \& Morison JIL (2005) Farm costs and food miles: an assessment of the full cost of the UK weekly food basket. Food Policy 30, 1-19.

26. Sosial- og helsedirektoratet (2005) Utviklingen $i$ norsk kosthold 2005. Matforsyningsstatistikk og forbruksundersøkelser. Oslo: Sosial- og helsedirektoratet.

27. Samuelsen R (1991) Kommersialisering av ville boer noeringsutvikling $i$ bygder. Tromsø: Bioforsk Holt.

28. Statens ernæringsråd (1996) Anbefalinger for økt inntak av frukt og grønnsaker. Oslo: Statens ernæringsråd.

29. Kardell L (1980) Occurrence and production of bilberry, lingonberry and raspberry in Sweden's forests. Forest Ecol Manage 2, 285-296.
30. Halvorsen BL, Holte K, Myhrstad MC et al. (2002) A systematic screening of total antioxidants in dietary plants. J Nutr 132, 461-471.

31. Bere E (2007) Wild berries: a good source of omega-3. EurJ Clin Nutr 61, 431-433.

32. Field RC (2000) Cruciferous and green leafy vegetables. In The Cambridge World History of Food, pp. 288-298 [KF Kiple and KC Ornelas, editors]. Cambridge: Cambridge University Press.

33. Murillo G \& Mehta RG (2001) Cruciferous vegetables and cancer prevention. Nutr Cancer 41, 17-28.

34. Bolton-Smith C, Price RJ, Fenton ST, Harrington DJ \& Shearer MJ (2002) Compilation of a provisional UK database for the phylloquinone (vitamin $\mathrm{K}_{1}$ ) content of foods. BrJ Nutr 83, 389-399.

35. Ayaz FA, Glew RH, Millson M, Huang HS, Chuang LT, Sanz C \& Hayirlioglu-Ayaz S (2006) Nutrient contents of kale (Brassica oleraceae L. var. acephala DC). Food Chem 96, 572-579.

36. Directorate for Fisheries (2006) Norges Fiskerier 2005. http://www.fiskeridir.no/fiskeridir/fiskeri/statistikk/fangst_ og_kvoter/norges_fiskerier (accessed August 2007).

37. Directorate for Fisheries (2006) Total sale of fish in the aquaculture industry. http://www.fiskeridir.no/fiskeridir/ kystsone_og_havbruk/statistikk/statistikk_for_akvakultur/totalt_ hele_n_ringen (accessed August 2007).

38. Statistics Norway (2004) Hjorteviltjakt. http://www.ssb.no/ emner/10/04/10/nos_jakt/nos_d311/tab/10.html (accessed August 2007).

39. Clutton-Brock J (1999) A Natural History of Domesticated Mammals, 2nd ed. Cambridge: Cambridge University Press.

40. Cordain L, Watkins BA, Florant GL, Kelher M, Rogers L \& Li Y (2002) Fatty acid analysis of wild ruminant tissues: evolutionary implications for reducing diet-related chronic disease. Eur J Clin Nutr 56, 181-191.

41. Norwegian Agricultural Authority (2007) Forbruk av korn til mat 1996-2006. http://www.slf.dep.no/portal/page? pageid $=53,418236 \&$ dad $=$ portal\&_schema $=$ PORTAL\&p_ d_i $=-121 \& p d \_c=8 p \_d \_v=1942 \& p \_d \_i=-221 \& p \_d$ _c $=\& p$ d_v $=1942$ (accessed August 2007).

42. Foster-Powell K, Holt SHA \& Brand-Miller JC (2002) International table of glycemic index and glycemic load values: 2002. Am J Clin Nutr 76, 5-56.

43. Sosial- og helsedirektoratet (2006) Utviklingen $i$ norsk kosthold 2006. Oslo: Sosial- og helsedirektoratet.

44. Cannon G \& Leitzman C (2005) The new nutrition science project. Public Health Nutr 8, 673-694.

45. Naylor RL, Goldburg RJ, Primavera JH, Kautsky N, Beveridge MC, Clay J, Folke C, Lubchenco J, Mooney H \& Troell M (2000) Effect of aquaculture on world fish supplies. Nature 405, 1017-1024.

46. Diamond J (1998) Guns, Germs and Steel. A Short History of Everybody for the Last 13000 Years. London: Vintage.

47. Pauly D, Christensen V, Guenette S, Pitcher TJ, Sumaila UR, Walters CJ, Watson R \& Zeller D (2002) Towards sustainability in world fisheries. Nature 418, 689-695.

48. Worm B, Barbier EB, Beaumont $\mathrm{N}$ et al. (2006) Impacts of biodiversity loss on ocean ecosystem services. Science 314, 787-790.

49. Pauly D \& MacLean J (2003) In a Perfect Ocean. The State of Fisheries and Ecosystems in the North Atlantic. Washington, DC: Island Press.

50. Halweil B (2006) Catch of the Day. Choosing Seafood for Healthier Oceans. Worldwatch Paper no. 172. Washington, DC: Worldwatch Institute.

51. Brug J, Oenema A \& Ferreira I (2005) Theory, evidence and Intervention Mapping to improve behavior nutrition and physical activity interventions. Int J Behav Nutr Phys Act 2, 2.

52. Rothschild ML (1999) Carrots, sticks, and promises: a conceptual framework for the management of public health and social issue behaviors. J Marketing 63, 24-37. 